\title{
Patterns and Sizes of Authigenic Carbonate Formation in the Pliocene Foreland in Southwestern Taiwan: Implications of an Ancient Methane Seep
}

\author{
Chih-Wei Chien ${ }^{1, *}$, Chi-Yue Huang ${ }^{1,2}$, Hong-Chun Lee ${ }^{1,3}$, and Kenn-Ming Yang ${ }^{1}$ \\ ${ }^{1}$ Department of Earth Sciences, National Cheng Kung University, Tainan, Taiwan \\ ${ }^{2}$ Department of Earth Sciences and Research Center of Ocean Environment and Technology, \\ National Cheng Kung University, Tainan, Taiwan \\ ${ }^{3}$ Department of Geosciences, National Taiwan University, Taipei, Taiwan
}

Received 3 September 2012, accepted 5 July 2013

\begin{abstract}
Several dolomitic authigenic carbonate concretions (ACCs) are preserved in the Pliocene foreland sequence in southwestern Taiwan. Carbon isotopic signatures and the morphology of these carbonates and associated chemosymbiotic bivalve fossils reveal their methane seep origin. There are three types of ACCs: (1) massive brecciated blocks (MBBs; $\delta^{13} \mathrm{C}=-49.57$ $\sim-38.20 \%$; $\delta^{18} \mathrm{O}=1.59 \sim 4.25 \%$ ); (2) giant chimneys (GCs; $\delta^{13} \mathrm{C}=-43.14 \sim-17.73 \%$; $\delta^{18} \mathrm{O}=-7.64 \sim 3.36 \%$ ); and (3) slender pipe networks (SPNs; $\delta^{13} \mathrm{C}=-43.51 \sim 5.91 \%$; $\delta^{18} \mathrm{O}=-6.90 \sim-3.57 \%$ ). Different shapes, sizes, stratigraphic positions, and carbon isotopic compositions are due to different flux/intensities and flow pattern of discharging methane. MBBs were derived from diffusion of methane and formed in deeper positions, whereas GCs mark the locations of feeder faults and main outlets of methane emission. SPNs formed along fractures or bedding planes; they were (1) accessories of MBBs and GCs, or (2) products of minor releases of residual geofluids. We compared ACCs of the Chiahsien Paleoseep to two previously studied cold seep carbonates within the same foredeep in southwestern Taiwan, which represent similar occurrences and stable carbon isotopic compositions. However, the older ACCs in the Chiahsien Paleoseep have undergone longer diagenesis and weathering processes and have more complicated and lower $\delta^{18} \mathrm{O}$ signatures. These asynchronous cold seep carbonates can indicate hydrocarbon migrations and fault activities within the orogenic belt of Taiwan.
\end{abstract}

Key words: Cold seep, Authigenic carbonate, Taiwan

Citation: Chien, C. W., C. Y. Huang, H. C. Lee, and K. M. Yang, 2013: Patterns and sizes of authigenic carbonate formation in the Pliocene foreland in southwestern Taiwan: Implications of an ancient methane seep. Terr. Atmos. Ocean. Sci., 24, 971-984, doi: 10.3319/TAO.2013.07.05.01(TT)

\section{INTRODUCTION}

Cold seeps are particular geological phenomena caused by the release of hydrocarbons or brines to the sea floor (Judd and Hovland 2007). In methane seeps, anaerobic oxidation of methane (AOM) carried out by a syntrophic consortium of methanotrophic archaea and sulfate reducing bacteria produces bicarbonate and hydrogen sulfide in sulfate-methane transition zones (SMTZ):

$\mathrm{CH}_{4}+\mathrm{SO}_{4}^{2-} \rightarrow \mathrm{HS}^{-}+\mathrm{HCO}_{3}^{-}+\mathrm{H}_{2} \mathrm{O}$

where elevated alkalinity accelerates the precipitation of au-

\footnotetext{
* Corresponding author

E-mail:blattus@gmail.com
}

thigenic carbonates (Aharon 2000; Lein 2004):

$\mathrm{HCO}_{3}^{-}+\mathrm{Ca}^{2+} \rightarrow \mathrm{CaCO}_{3}+\mathrm{H}^{+}$

Campbell (2006) reviewed the worldwide distributions of modern and ancient cold seeps, where authigenic carbonates form in several shapes such as chimneys, pipes, crusts, blocks and mounts. Remarkable chemosymbiotic fauna, including lucinid, solemyid, and vesicomyid bivalves, and vestimentiferan tubeworms also can be found in modern and ancient cold seeps (e.g., lucinid, solemyid, and vesicomyid bivalves, and vestimentiferan tubeworms; Sibuet and Olu 1998; Levin 2005). For example, deep-sea mussel (Bathymodiolus platifrons) and galatheid crab (Shinkaia crosnieri) 
colonies have been found in modern active cold seep area in syn-collision accretionary prisms offshore southwestern Taiwan (Liu et al. 2008).

As one of the most active orogenic belts in the world since the Late Miocene, the pre- to syn-collision accretionary prism of Taiwan (Huang et al. 1997, 2000) provides an ideal site for hydrocarbon formation and accumulation, and the densely distributed faults can act as conduits for hydrocarbon migration and release. There are many related geological phenomena, including active offshore mud diapirs (Chiu et al. 2006), cold seep sites (Huang et al. 2006), onshore mud volcanoes (Shih 1967; Yang et al. 2004; Chiu et al. 2006), and cold seep remnants from the Miocene (Chien et al. 2012) to the Pleistocene (Wang et al. 2006), dispersed within the Taiwan orogenic belt.

It is difficult to observe an offshore cold seep panoramically due to the limited accessibility. Additionally, offshore ACCs are commonly covered by sediments (unless they precipitated on the sea floor, or outcrop by bottom-current erosion). In contrast, on-land exposure of cold seep remnants is valuable because of the convenience for sampling and directly observations that allows more detailed examination of the three-dimensional morphology. In this study, we recognized an onshore cold seep remnant in the Pliocene foreland sequences of southwestern Taiwan based on the multiple morphology of ACCs and their stable carbon isotope signatures. These ACCs were previously ignored or were misinterpreted as mysterious trace fossils (Yeh and Chang 1991). We also compared these paleoseep ACCs to two previously studied cold-seep-origin carbonates also located in southwestern Taiwan area but with younger ages (Huang et al. 2006; Wang et al. 2006), and attempted to reveal the evolutionary relationship of the formations and preservations of the cold seeps in southwestern Taiwan.

\section{GEOLOGICAL SETTING AND METHODS}

The orogeny of Taiwan is the result of a collision between the Luzon Arc on the Philippine Sea Plate and the Eurasian continental margin (Suppe 1984; Huang et al. 2000; Fig. 1). The active fold-and-thrust belt in western Taiwan, the Western Foothills Zone, is composed of Miocene shelfslope to Pliocene-Pleistocene foreland basin deposits, and was incorporated into the accretionary prism during the arccontinent collision in the last 2 million years (Liu et al. 1998; Huang et al. 2000, 2001). This exposed accretionary prism provides large amounts of organic material and terrestrial sediments into the ancient foredeep and the modern Kaoping Slope. This geological setting favors the formation and accumulation of hydrocarbon geofluids. There are many active mud volcanoes, mud diapirs, and natural gas/oil seepages associated with $\mathrm{CH}_{4}$ or $\mathrm{CO}_{2}$ releases in the Western Foothills Zone and the Kaoping Slope (Shih 1967; Yang et al. 2004; Chiu et al. 2006; Chen et al. 2010; Sun et al. 2010) (Fig. 1).
The paleoseep remnant studied here is located in the Chiahsien area, and is preserved in the foreland basin sequence within the Western Foothills Zone (Fig. 1). Rock strata at the paleoseep outcrops are from the Late Miocene Tangenshan Sandstone to the Pliocene Yenshuikeng Shale (Chung 1962) (Figs. 1, 2). Trace fossil analysis indicates that the depositional environment changed from an inner shelf to a middle shelf environment (Ting et al. 1991; Yeh and Chang 1991). The outcrops containing paleoseep ACCs are within the Yenshuikeng Shale, surrounded between the low-angle Pinghsi Thrust Fault and the high-angle Chishan Thrust Fault and crossed by the sinistral Tishui Strike-slip Fault (Fig. 1; Sung et al. 2000).

We collected 66 samples from three types of ACCs (see details in results) and 5 samples of calcite veins for stable carbon and oxygen isotopic analysis (Fig. 2). Oxygen and carbon isotopic analyses were carried out using a Finnigan Delta Plus XP mass spectrometer coupled to a Kiel III device at the Department of Earth Sciences, National Cheng Kung University. Isotopic compositions are shown using the conventional delta notation expressed relative to the Vienna PeeDee Belemnite (VPDB) standard. The calibrated working standards were NBS-19, NBS-18 and LSVEC $\left(\mathrm{Li}_{2} \mathrm{CO}_{3}\right)$. The standard deviation of repeated sample measurements was less than 0.03 and $0.04 \%$ for $\delta^{13} \mathrm{C}$ and $\delta^{18} \mathrm{O}$, respectively.

Mineral compositions of ACC samples containing adequate sample material were analyzed by X-ray diffraction (XRD) analyses with a Bruker D8 Advance diffractometer at the Department of Earth Sciences, National Cheng Kung University. Measurements were made from $8^{\circ}$ to $80^{\circ} 2 \theta$ with a step size of $0.01^{\circ} 2 \theta$ at $40 \mathrm{kV} / 40 \mathrm{~mA}$. The XRD data were analyzed with the TOPAZ software based on the Rietveld method (Rietveld 1967; Young 1993; Mumme et al. 1996) to determine mineral elemental abundances (wt\%). Results were considered statistically significant if Goodness of Fits (GoF) were in the range of 1 to 1.7 with low weighted profile $\mathrm{R}$-factor $\left(\mathrm{R}_{\mathrm{wp}} ;<15\right.$ is better). More detailed discussions about R-factor and GoF are in Young (1993) and Toby (2006).

\section{RESULTS}

\subsection{Morphology of ACCs}

The authigenic carbonates investigated in this study were primarily from two exposures within an area of about $2.5 \times 4 \mathrm{~km}$. Exposure A (Fig. 3a) is a vertical cliff dipping to Exposure B (Figs. 1, 2). Three different types of authigenic carbonates occur in the study area based on their appearance and location.

These are:

(1) massive brecciated blocks (MBBs; typically 2 to $4 \mathrm{~m}$ long, 1 to $2 \mathrm{~m}$ wide, and 3 to $5 \mathrm{~m}$ high) are large, solid, dense, whitish gray to grayish yellow, mound-shaped carbonate bodies, with or without vent and pipe structures, in 
Exposure A along the Chihshanhsi River (Figs. 2, 3b - c). Chemosymbiotic lucinid pelecypods Anadontia goliath (Yokoyama) (K. Matsuda, personal communication; Taylor and Glover 2009) fossils were found within MBBs.

(2) Giant chimneys (GCs; circa 2 to $5 \mathrm{~m}$ wide and $30 \mathrm{~m}$ high) are large and thick cylindrical or fusiform concretions developing upwardly perpendicular to the bedding in Exposure A (Figs. 2, 3d). They occur either in isolation or parallel to each other, and contain vent/pipe structures (diameter $>15 \mathrm{~cm}$ ) clustered with irregular shaped


Fig. 1. Geological map of the Chiahsien area, southwestern Taiwan (after Sung et al. 2000) and mud volcano locations onshore (Shih 1967) and offshore (Chiu et al. 2006). WF: Western Foothills; KS: Kaoping Slope; TKS: Takanshan Limestone; LF: Lishan Fault; CKF: Chukou Fault; CF: Chishan Fault; DF: deformation front.

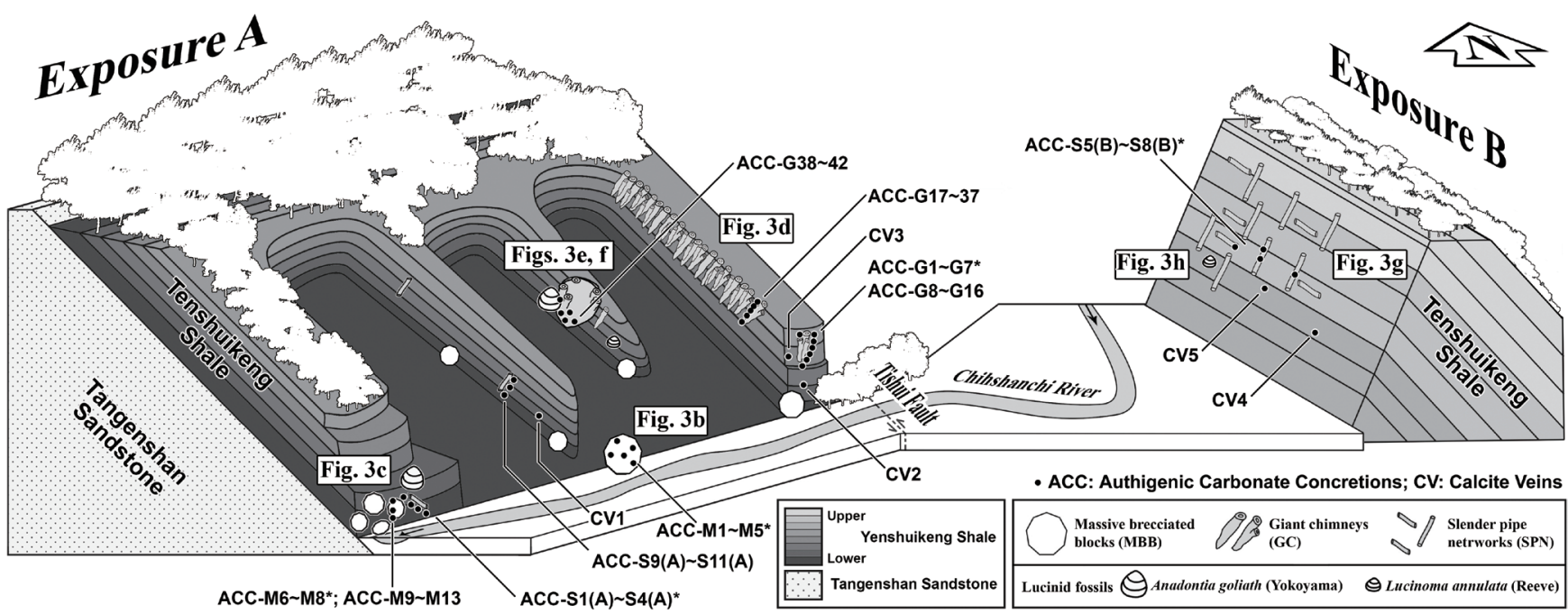

Fig. 2. Semi-schematic diagram of outcrops, distribution and occurrences of three types of ACCs and licinid fossils, and sampling locations. The attitude of strata is $\mathrm{N}^{\circ} 0^{\circ} \mathrm{E}, 35^{\circ} \mathrm{E}$. Dip angle and distance are not in scale. Sample numbers marked with a star means that these samples were also used for XRD analysis. 

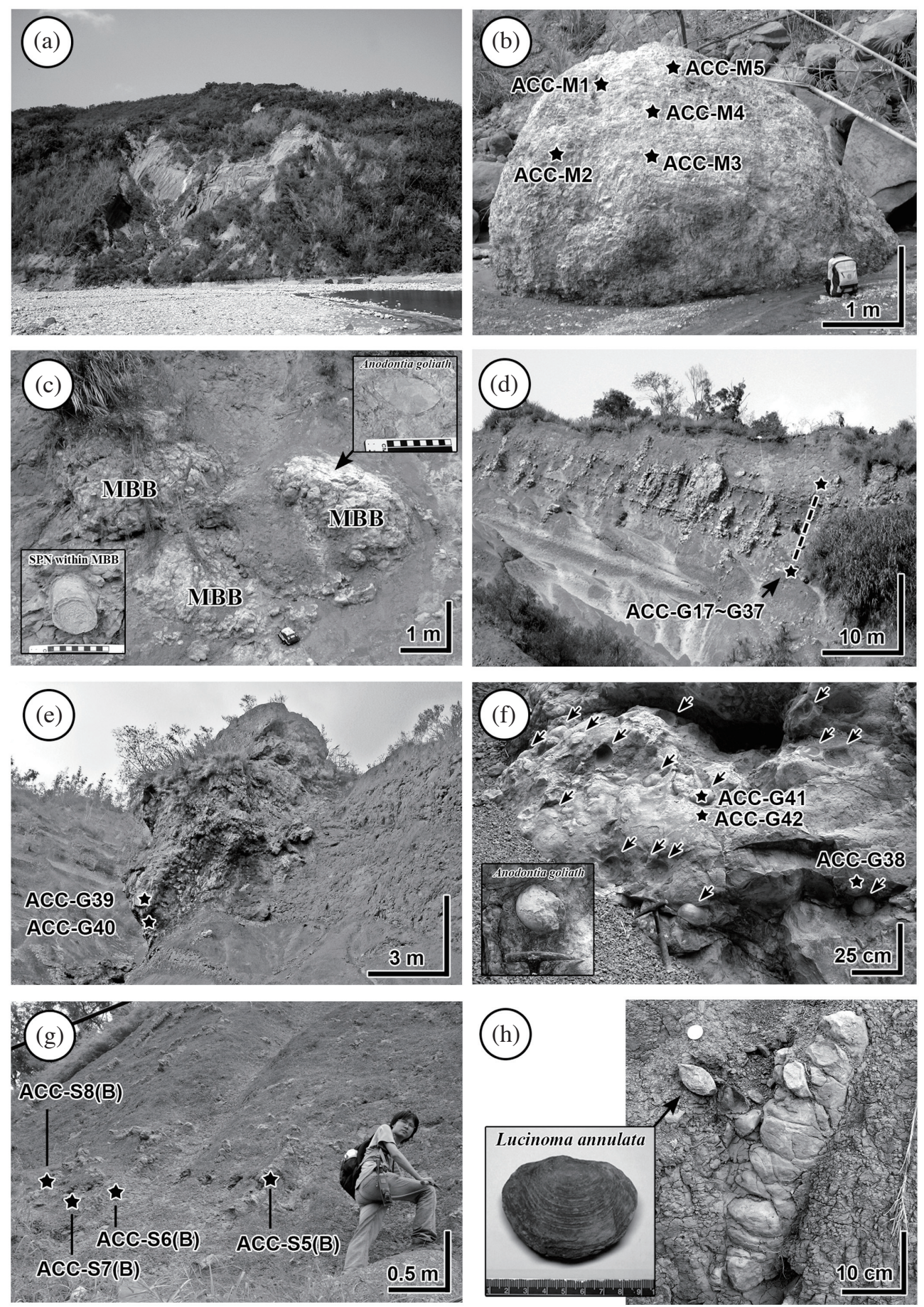

Fig. 3. Photographs of the Chiahsien Paleoseep outcrops: (a) Exposure A panorama; (b) a MBB type ACC in the Exposure A near the Chihshanchi River; (c) MBBs and their associated lucinid fossil and SPN type ACC in an outcrop in Exposure A along the Chihshanchi River; (d) GC "wall" in the Exposure A; (e) a fusiform GC type ACC in Exposure A; (f) numerous Anodontia goliath (Yokoyama) mould fossils (pointed by arrows) in situ located near the fusiform GC; (g) SPN type ACC in the Exposure B; and (h) an in situ but deformed Lucinoma annulata (Reeve) fossil associated with a SPN type concretion.

carbonates. Abundant in situ Anodontia goliath (Yokoyama) fossils (Fig. 3e) occur in the margin of one large fusiform GC body (size: circa $5 \times 5 \times 10 \mathrm{~m}$; Fig. 3f). There are a series of GCs (Fig. 3d) combined to form a "wall" adjacent and parallel to the Tishui Fault (Figs. 1,2).
(3) Slender pipe networks (SPNs) are composed of elongated small carbonate cylinders with diameters commonly between 5 and $15 \mathrm{~cm}$. They are found in both Exposure A and B, and the bank of the Chihshanhsi river (Figs. 1, 2). These pipe-shaped concretions were previously considered 
as an "unknown trace fossil" (Yeh and Chang 1991). The "pipes" develop upwardly perpendicular to the host mudstone bedding, typically separated from each other by 1 to $2 \mathrm{~m}$, with some occurring branched or connected horizontally to the same pipes (Figs. $2,3 \mathrm{~g}$ ). We also found a few Lucinoma annulata (Reeve) lucinid fossils together with some pipes (Fig. 3h).

\subsection{Carbon and Oxygen Isotope and Mineral Composi- tions of ACCs}

The stable carbon and oxygen isotope compositions of the Chiahsien Paleoseep carbonates are shown in Fig. 4a and listed in Table 1. The $\delta^{13} \mathrm{C}$ values range from -49.57 to $+5.91 \%$, with the values for MBBs (range, -49.57 to

(a)



(b)



(c)

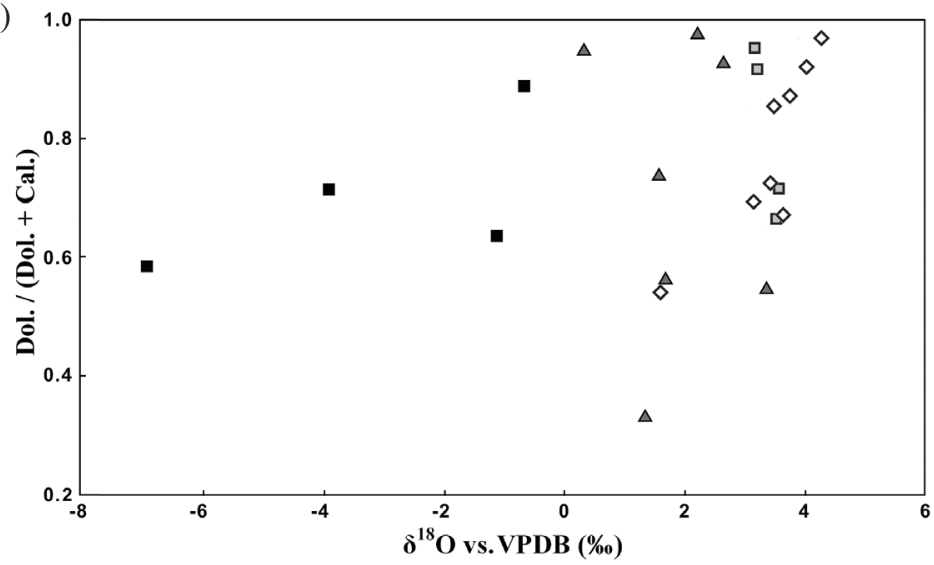

Fig. 4. Plot of carbon and oxygen isotopic compositions and dolomite percentages for the three types of ACCs: (a) $\delta^{18} \mathrm{O}$ versus $\delta^{13} \mathrm{C}$; (b) $\delta^{13} \mathrm{C}$ versus dolomite percentages; and (c) $\delta^{18} \mathrm{O}$ versus dolomite percentages. Dol. $=$ dolomite; Cal. $=$ calcite. Data are also shown in Table 1. Published data for the inland Pleistocene Takangshan cold seep carbonates in southwestern Taiwan (Wang et al. 2006) and the ACCs in the Kaoping Slope offshore southwestern Taiwan (Huang et al. 2006) are also plotted to compare with the carbon and oxygen isotopic compositions in this study. 
Table 1. Mineral and isotopic compositions of the Chiahsien Paleoseep ACC samples.

\begin{tabular}{|c|c|c|c|c|c|c|c|c|c|c|c|}
\hline \multirow{2}{*}{ Sample } & \multicolumn{2}{|c|}{ Stable Isotops } & \multicolumn{3}{|c|}{ Mineral compositions (wt\%) } & \multirow{2}{*}{ Feldspar } & \multirow{2}{*}{ Muscovite } & \multirow{2}{*}{ Gypsum } & \multirow{2}{*}{ Clay minerals } & \multicolumn{2}{|c|}{ Criteria of fit } \\
\hline & $\delta^{13} \mathrm{C}_{\mathrm{VPDB}}$ & $\delta^{18} O_{\mathrm{VPDB}}$ & Calcite & Dolomite & Quartz & & & & & Rwp & GoF \\
\hline \multicolumn{12}{|l|}{ MBB } \\
\hline ACC-M1 & -48.44 & 3.73 & 10.85 & 73.34 & 3.58 & 3.02 & 7.26 & & 1.94 & 30.70 & 1.28 \\
\hline ACC-M2 & -46.67 & 4.25 & 2.61 & 78.86 & 6.02 & 4.56 & 1.52 & & 6.43 & 31.36 & 1.30 \\
\hline ACC-M3 & -49.57 & 3.49 & 12.83 & 74.25 & 5.72 & 2.15 & 0.76 & & 4.28 & 31.67 & 1.32 \\
\hline ACC-M4 & -45.38 & 4.01 & 5.93 & 66.97 & 6.88 & 3.31 & 7.78 & & 9.12 & 37.53 & 1.66 \\
\hline ACC-M5 & -45.53 & 3.14 & 23.54 & 52.90 & 5.97 & 7.91 & & & 9.67 & 31.52 & 1.36 \\
\hline ACC-M6 & -42.68 & 3.42 & 21.35 & 55.71 & 6.95 & 5.28 & 2.81 & & 7.90 & 31.57 & 1.36 \\
\hline ACC-M7 & -44.44 & 3.61 & 26.42 & 53.37 & 6.78 & 5.97 & 2.57 & & 4.88 & 31.19 & 1.27 \\
\hline ACC-M8 & -38.20 & 1.59 & 36.38 & 42.77 & 7.46 & 4.16 & 1.25 & & 7.97 & 31.31 & 1.33 \\
\hline ACC-M9 & -42.71 & 3.22 & & & & & & & & & \\
\hline ACC-M10 & -43.74 & 3.67 & & & & & & & & & \\
\hline ACC-M11 & -44.55 & 3.43 & & & & & & & & & \\
\hline ACC-M12 & -43.56 & 3.09 & & & & & & & & & \\
\hline ACC-M13 & -43.01 & 3.15 & & & & & & & & & \\
\hline \multicolumn{12}{|l|}{ GC } \\
\hline ACC-G1 & -30.42 & 1.33 & 51.43 & 25.46 & 11.39 & 2.66 & 0.27 & & 8.81 & 29.55 & 1.36 \\
\hline ACC-G2 & -39.52 & 3.36 & 39.23 & 47.12 & 4.78 & 1.84 & 1.76 & & 5.27 & 30.28 & 1.29 \\
\hline ACC-G3 & -35.17 & 2.21 & 1.93 & 82.52 & 4.58 & 2.80 & 1.85 & & 6.30 & 29.69 & 1.24 \\
\hline ACC-G4 & -37.45 & 2.64 & 4.99 & 65.30 & 7.43 & 6.26 & 5.76 & & 10.27 & 28.83 & 1.22 \\
\hline ACC-G5 & -18.29 & 0.30 & 4.04 & 73.85 & 9.99 & 3.74 & 0.33 & & 8.06 & 31.28 & 1.33 \\
\hline ACC-G6 & -27.07 & 1.67 & 33.98 & 43.93 & 8.09 & 3.03 & 2.49 & & 8.48 & 29.38 & 1.23 \\
\hline ACC-G7 & -30.51 & 1.57 & 16.53 & 46.81 & 14.80 & 4.98 & 7.53 & & 9.35 & 31.74 & 1.38 \\
\hline ACC-G8 & -32.19 & 0.40 & & & & & & & & & \\
\hline ACC-G9 & -31.50 & 1.92 & & & & & & & & & \\
\hline ACC-G10 & -29.16 & -2.47 & & & & & & & & & \\
\hline ACC-G11 & -39.06 & 2.93 & & & & & & & & & \\
\hline ACC-G12 & -32.90 & 2.68 & & & & & & & & & \\
\hline ACC-G13 & -34.79 & 3.33 & & & & & & & & & \\
\hline ACC-G14 & -30.88 & 2.75 & & & & & & & & & \\
\hline ACC-G15 & -23.00 & -0.96 & & & & & & & & & \\
\hline ACC-G16 & -17.73 & 0.43 & & & & & & & & & \\
\hline ACC-G17 & -31.58 & 1.18 & & & & & & & & & \\
\hline ACC-G18 & -32.10 & 0.69 & & & & & & & & & \\
\hline ACC-G19 & -34.27 & 0.71 & & & & & & & & & \\
\hline ACC-G20 & -34.84 & 1.95 & & & & & & & & & \\
\hline ACC-G21 & -29.36 & -0.82 & & & & & & & & & \\
\hline ACC-G22 & -37.94 & 2.08 & & & & & & & & & \\
\hline ACC-G23 & -34.55 & 1.64 & & & & & & & & & \\
\hline
\end{tabular}


Table 1. (Continued)

\begin{tabular}{|c|c|c|c|c|c|c|c|c|c|c|c|}
\hline \multirow{2}{*}{ Sample } & \multicolumn{2}{|c|}{ Stable Isotops } & \multicolumn{3}{|c|}{ Mineral compositions (wt\%) } & \multirow{2}{*}{ Feldspar } & \multirow{2}{*}{ Muscovite } & \multirow{2}{*}{ Gypsum } & \multirow{2}{*}{ Clay minerals } & \multicolumn{2}{|c|}{ Criteria of fit } \\
\hline & $\delta^{13} C_{\text {VPDB }}$ & $\delta^{18} \mathbf{O}_{\mathrm{VPDB}}$ & Calcite & Dolomite & Quartz & & & & & Rwp & GoF \\
\hline ACC-G24 & -38.00 & 1.57 & & & & & & & & & \\
\hline ACC-G25 & -35.51 & 1.42 & & & & & & & & & \\
\hline ACC-G26 & -37.33 & 2.31 & & & & & & & & & \\
\hline ACC-G27 & -36.32 & 2.73 & & & & & & & & & \\
\hline ACC-G28 & -34.10 & 2.10 & & & & & & & & & \\
\hline ACC-G29 & -40.81 & 1.63 & & & & & & & & & \\
\hline ACC-G30 & -23.30 & -1.86 & & & & & & & & & \\
\hline ACC-G31 & -26.01 & -2.13 & & & & & & & & & \\
\hline ACC-G32 & -39.71 & 2.82 & & & & & & & & & \\
\hline ACC-G33 & -43.14 & 2.77 & & & & & & & & & \\
\hline ACC-G34 & -19.67 & -7.64 & & & & & & & & & \\
\hline ACC-G35 & -36.62 & 1.60 & & & & & & & & & \\
\hline ACC-G36 & -42.46 & 2.33 & & & & & & & & & \\
\hline ACC-G37 & -39.99 & 1.06 & & & & & & & & & \\
\hline ACC-G38 & -40.96 & 0.61 & & & & & & & & & \\
\hline ACC-G39 & -42.81 & 1.21 & & & & & & & & & \\
\hline ACC-G40 & -42.59 & 1.58 & & & & & & & & & \\
\hline ACC-G41 & -37.96 & 0.85 & & & & & & & & & \\
\hline ACC-G42 & -34.46 & -2.10 & & & & & & & & & \\
\hline \multicolumn{12}{|l|}{ SPN } \\
\hline ACC-S1(A) & -42.47 & 3.19 & 3.80 & 75.55 & 10.35 & 1.78 & 4.36 & & 4.17 & 36.92 & 1.29 \\
\hline ACC-S2(A) & -42.94 & 3.23 & 6.41 & 72.58 & 8.69 & 5.33 & 2.60 & & 4.39 & 35.81 & 1.28 \\
\hline ACC-S3(A) & -43.51 & 3.53 & 27.87 & 55.87 & 7.18 & 3.02 & 1.90 & & 4.16 & 29.72 & 1.28 \\
\hline ACC-S4(A) & -42.86 & 3.57 & 22.76 & 57.76 & 5.60 & 3.33 & 4.48 & & 6.07 & 32.01 & 1.34 \\
\hline ACC-S5(B) & -0.74 & -3.92 & 20.89 & 52.81 & 7.90 & 3.88 & 8.66 & 0.47 & 5.40 & 35.67 & 1.20 \\
\hline ACC-S6(B) & -7.74 & -6.90 & 23.54 & 33.30 & 11.98 & 6.93 & 12.47 & 3.90 & 7.89 & 37.10 & 1.24 \\
\hline ACC-S7(B) & 0.96 & -1.10 & 23.11 & 40.22 & 11.68 & 4.32 & 14.72 & & 5.96 & 33.08 & 1.37 \\
\hline ACC-S8(B) & 5.91 & -0.66 & 8.26 & 66.63 & 7.60 & 3.34 & 12.11 & & 2.05 & 31.73 & 1.30 \\
\hline ACC-S9(A) & -29.77 & -0.48 & & & & & & & & & \\
\hline ACC-S10(A) & -28.75 & 0.00 & & & & & & & & & \\
\hline ACC-S11(A) & -36.78 & 1.01 & & & & & & & & & \\
\hline \multicolumn{12}{|l|}{ Calcite Veins } \\
\hline $\mathrm{CV} 1$ & -8.45 & -11.37 & & & & & & & & & \\
\hline $\mathrm{CV} 2$ & -25.92 & -12.49 & & & & & & & & & \\
\hline CV3 & -29.91 & -12.00 & & & & & & & & & \\
\hline $\mathrm{CV} 4$ & -9.07 & -9.20 & & & & & & & & & \\
\hline CV5 & -12.69 & -9.15 & & & & & & & & & \\
\hline Uncertainty & \pm 0.03 & \pm 0.04 & & & & & & & & & \\
\hline
\end{tabular}


$-38.20 \%, \mathrm{n}=13$ ) lower than the values for GCs (range, -43.14 to $-17.73 \%, \mathrm{n}=42$ ) and SPNs (range, -43.51 to $+5.91 \%, \mathrm{n}=11$ ). The SPNs associated with MBBs and GCs had a similar range of $\delta^{13} \mathrm{C}$ values to each other (Figs. 2, 4a; Table 1). SPNs in Exposure A had lower $\delta^{13} \mathrm{C}$ values (range, -43.51 to $-28.75 \%$ ) than the $\delta^{13} \mathrm{C}$ values for SPNs in Exposure B $(-7.74$ to $+5.91 \%$ ) .

The $\delta^{18} \mathrm{O}$ values range from -7.64 to $+4.25 \%$, with the values for MBBs $(+1.59$ to $+4.25 \%$ ) higher than the values for GCs $(-7.64$ to $+3.36 \%$ ) and for SPNs $(-6.90$ to $+3.57 \%$ ) . The SPNs had a similar range of $\delta^{13} \mathrm{C}$ values for MBBs and GCs for the same location (Figs. 2, 4a; Table. 1). SPNs of Exposure $\mathrm{A}$ had higher $\delta^{18} \mathrm{O}$ values (range, -0.48 to $+3.57 \%$ ) than the $\delta^{18} \mathrm{O}$ values in Exposure B (range, -6.90 to $-0.66 \%$ ).

The ACCs are mainly composed of dolomitic and calcitic micrite with terrigenous minerals such as quartz, muscovite, and feldspar, and clay minerals (Table 1). Two SPNs in Exposure B contain gypsum. Some SPNs are filled in the center with secondary precipitated calcite spars. Dolomite percentages (the ratio of dolomite wt $\%$ and the sum of dolomite wt $\%$ and calcite wt $\%$ ) are very high (>0.95) in four samples [ACC-M2, ACC-G3, ACC-G5 and ACC-S1 (A)]; only one sample (ACC-G1) has a dolomite percentage below 0.5 .

Carbon and oxygen isotopic compositions showed different correlations with dolomite percentages among the three types of ACCs (Fig. 4b, c). There was a highly negative correlation between $\delta^{13} \mathrm{C}$ values and dolomite percentages for the MBBs (correlation coefficient $\mathrm{R}=-0.7718$ ), but a highly positive correlation between $\delta^{18} \mathrm{O}$ values and dolomite percentages $\left(R=0.8612\right.$ ). Both $\delta^{13} \mathrm{C}$ and $\delta^{18} \mathrm{O}$ values for the GCs were weakly correlated to dolomite percentages ( $R=0.1060$ and -0.0929 , respectively). The SPNs in Exposure A showed a highly positive correlation between $\delta^{13} \mathrm{C}$ values and dolomite percentages $(\mathrm{R}=0.7711)$. In contrast, there was a highly negative correlation between $\delta^{18} \mathrm{O}$ values and dolomite percentages $(R=-0.9778)$. SPNs in Exposure $\mathrm{B}$ showed a highly positive correlation between $\delta^{13} \mathrm{C}$ values and dolomite percentages $(\mathrm{R}=0.8597)$, but a moderate positive correlation between $\delta^{18} \mathrm{O}$ values and dolomite percentages $(R=0.6527)$.

\section{DISCUSSION}

\subsection{Morphology and Mechanisms for the Formation of the Chiahsien Paleoseep ACCs}

Coexistence among the three types of ACCs and the lucinid fossils (Figs. 2, 3c, f, h) shows that these carbonates precipitated near the sediment-water boundary, because these chemosymbiotic bivalves dwell in the uppermost tens of centimeters of sediments (Stanley 1970) and close to the redox boundary (i.e., the SMTZ where the authigenic carbonates precipitated) (Taylor and Glover 2000). Bouchet and Cosel (2004) reported an extant large lucinid Megano- dontia acetabulum with similar size and outline to Anodotia goliath, but its extremely low umbone is different from the latter. Despite of the synapomorphically chemosymbiotic characteristics for all members of Lucinidae, the taxonomical and evolutionary relationships between the two species is still unclear (Taylor and Glover 2000).

The plots of carbon and oxygen isotopic compositions of the Chiahsien Paleoseep ACCs seem to be distributed on two mixing lines for Exposure A and B. These two lines "converge" to the meteoric end member which is derived from the low $\delta^{18} \mathrm{O}(<-8 \%)$ of the calcite veins (Fig. 4a). Oxygen isotopes are more prone to exchange than carbon isotopes in carbonate rocks, and trend to be ${ }^{18} \mathrm{O}$-depleted during rock alterations with meteoric waters (Peckmann and Thiel 2004; Campbell 2006). Figure 4a shows that most ACCs have undergone meteoric alterations, and mixing/interlacing between ACCs and meteoric water derived calcite vein was common with various extents. The other end members are the ACCs in Exposure A $\left(\delta^{13} \mathrm{C}: \sim-50 \%\right.$; $\left.\delta^{18} \mathrm{O}: \sim+4 \% 0\right)$ and of Exposure B $\left(\delta^{13} \mathrm{C}: \sim+7 \%\right.$; $\left.\delta^{18} \mathrm{O}: \sim 0 \%\right)$, which must be derived from quite different carbon sources.

The low $\delta^{13} \mathrm{C}$ values indicate that methane is the major carbon source of MBB, GC, and SPN concretions in Exposure A (Fig. 4a). The carbon sources for seep carbonates are mainly derived from anaerobically oxidized methane $\left(\delta^{13} \mathrm{C}\right.$ range -40 to $-50 \%$ o for thermogenic methane, and from -50 to $-100 \%$ or for biogenic methane). Therefore, extremely low $\delta^{13} \mathrm{C}$ values (typically $<-30 \%$ ) are likely signatures of seep carbonates (Aharon 2000; Campbell 2006). Since these different types of concretions occur in the same outcrop and are quite near each other (Fig. 2), differences in their ranges of $\delta^{13} \mathrm{C}$ values may derive from different mixtures of carbon sources rather than from different methane sources (thermogenic or biogenic). The carbon sources may be (1) oxidized methane in pore water with low $\delta^{13} \mathrm{C}(-40$ to $-100 \%$ ), (2) dissolved inorganic carbon (DIC) in seawater with higher $\delta^{13} \mathrm{C}(+2$ to $-2 \%$ ), and (3) diagenesis of sediment organic matter $\left(\delta^{13} \mathrm{C}\right.$ : -15 to $-35 \%$ ) (Campbell 2006). Logically, higher methane flux should produce more ${ }^{13} \mathrm{C}$-depleted bicarbonate in pore water, and precipitate more ${ }^{13} \mathrm{C}$-depleted ACCs (scenario 1). However, a higher methane flux will also decrease the depth of SMTZ (Borowski et al. 1996), causing DIC in seawater and organic matter to have more opportunity to take part in the precipitation of authigenic carbonates, thus producing ${ }^{13} \mathrm{C}$-enriched ACCs. Conversely, a lower methane flux will increase the depth of SMTZ, readily forming self-sealed ACCs (Figs. 5a - c). In addition, at the same site, $\delta^{13} \mathrm{C}_{\text {methane }}$ values tend to be lower with increasing sediment depth due to fractionation associated with AOM (Tsunogai et al. 2002) (scenario 2). Between the two alternative scenarios, we infer that $\delta^{13} \mathrm{C}$ of ACCs are principally controlled by differences in the mixing proportions between pore water and seawater due to differences in the depths of SMTZ together with the isotopic fractionation 
(a)

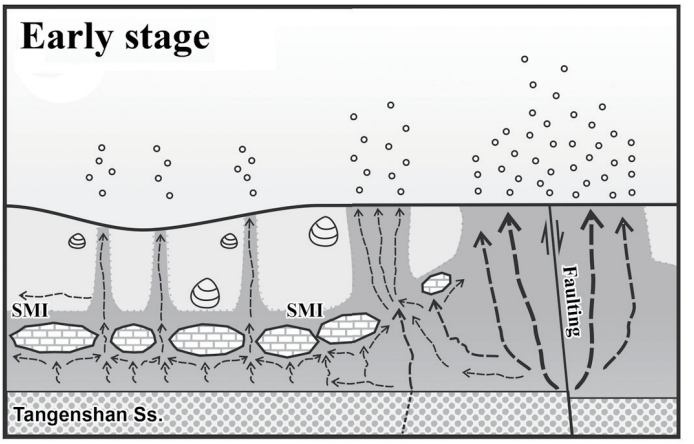

(c)

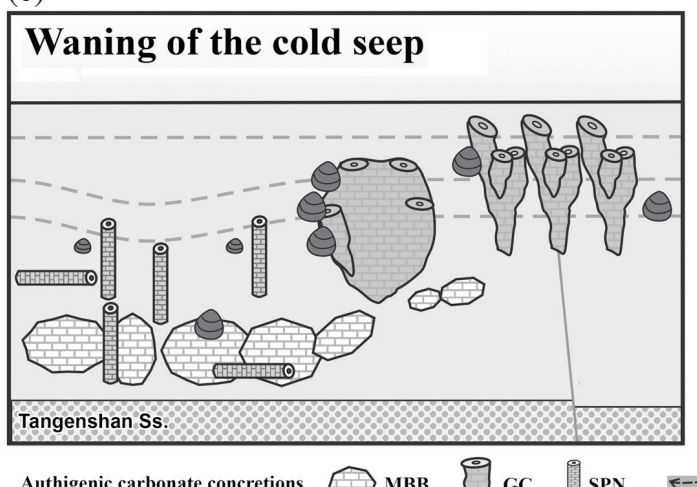

(b)



(d)

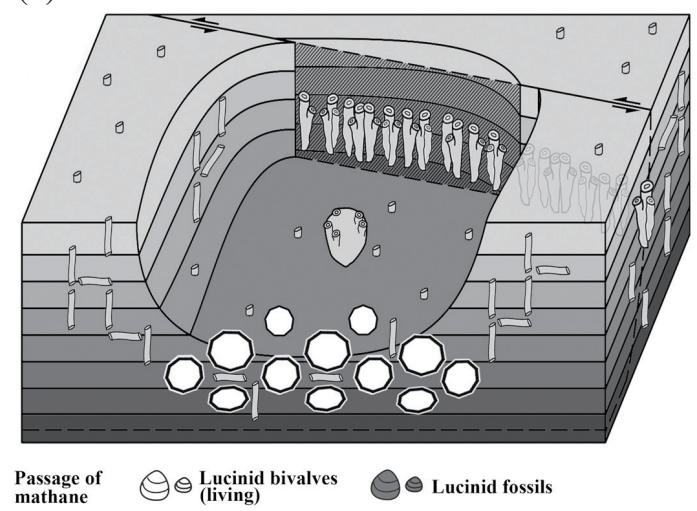

Fig. 5. Schematic for evolution (a - c) and reconstruction (d) of the Chiahsien Paleoseep (only for Exposure A). Dimensions are not in scale.

associated with AOM (i.e., scenario 2). This can plausibly explain that the GCs are found at higher stratigraphic positions than MBBs and are more enriched in ${ }^{13} \mathrm{C}$, and MBBs usually have denser and more solid texture than GCs. However, the methane fluxes in the Chiahsien Paleoseep should be low to moderate level because of presence of the isolated to grouped ACCs (mineral-prone substrate) (sensu Roberts 2001) and a low diversity of chemosymbiotic fauna (although we suggest that this is questionable due to poor preservation of macrofossils in the outcrops).

Overall, GCs occur at higher stratigraphic positions than MBBs with partially overlapping (Fig. 5), and SPNs occur in widest range whether horizontally or vertically (Figs. 1,2). This suggests that the size, shape, and distributing of authigenic carbonates relate to flux and flow pattern of released methane: MBBs were formed by weaker diffusion of methane; in advection-dominated regimes, the major venting occurred along the geofluid feeder conduits and formed GCs, whereas minor venting/seeping occurred along bedding planes and fractures in a wider range and formed SPNs (Fig. 5a - c). Chimney- and pipe-shaped ACCs suggest that fluid expulsion was highly channelized (Stakes et al. 1999).

Exposure B is situated in the upper part of the Yenshuikeng Shale, i.e., it is stratigraphically younger than Exposure A, which is situated in the lower part of the Yen- shuikeng Shale (Figs. 1, 2). ACCs of Exposure B are all SPN type and may have different carbon source(s) from the ACCs of Exposure A. The range of carbon isotope values of SPNs of Exposure B (Fig. 4; Table 1) indicates that they should be derived from another carbon source, e.g., residual $\mathrm{CO}_{2}$ from methanogenesis $\left(\delta^{13} \mathrm{C}:+5\right.$ to $+24 \%$, Campbell 2006) and/or ${ }^{13} \mathrm{C}$-enriched hydrocarbon, instead of methane. Elevated $\delta^{13} \mathrm{C}$ values of SPNs of Exposure B may be derived from a mixture of ${ }^{13} \mathrm{C}$-depleted methane and ${ }^{13} \mathrm{C}$ enriched residual $\mathrm{CO}_{2}$. We infer that the geofluid feeder (e.g., faults) had reached a deeper reservoir in the later stage of the development of the Chiahsien Paleoseep and formed these ${ }^{13} \mathrm{C}$-enriched SPNs in Exposure B.

Cold seeps are highly associated with geological structures, especially faults, in various tectonic settings (Sample and Reid 1998; Aiello 2005; Gay et al. 2007; Judd and Hovland 2007; Zitter et al. 2008; Barnes et al. 2010; Conti et al. 2010; Netzeband et al. 2010). Sample and Reid (1998) concluded that the fluid sources for precipitating ACCs were controlled predominately by different fault regimes. High-angle faults (commonly normal or strike-slip faults) may act as conduits for shallower fluids to form ${ }^{13} \mathrm{C}$-depleted//18 $\mathrm{O}$-enriched carbonates, or connect deeper and warmer sources to form ${ }^{13} \mathrm{C}$-enriched $/{ }^{18} \mathrm{O}$-depleted carbonates. Because cold seep carbonates precipitated on the sea floor or within the uppermost sediments, their formation ages are penecontemporaneous 
to the age of host sediments. Therefore, if there are any faults as the geofluid feeder for the Chiahsien Paleoseep, they should have been active in the Early Pliocene (i.e., the age of the Yenshuikeng Shale). Several small normal faults may have developed in the foreland region during the Early Pliocene. We suggest that some of these faults could act as the geofluid feeders to the Chiahsien Paleoseep. In early stage of the Paleoseep, the offset of the feeder faults should be small and provided shallower fluids to form ${ }^{13} \mathrm{C}$-depleted $/{ }^{18} \mathrm{O}$-enriched carbonates (e.g., MBBs, GCs and SPNs in Exposure A). The offset of the feeder fault(s) became greater and provided deeper fluids to form ${ }^{13} \mathrm{C}$-enriched $/{ }^{18} \mathrm{O}$-depleted carbonates (e.g., SPNs in Exposure B).

According to the relationship between the morphology of the ACCs and patterns in geofluid flow we infer that the series of GCs (the "wall", Figs. 2, 3d) indicates the main feeder fault (Figs. 5a, b) which may have been reactivated as the Tishui Fault later. The isolated fusiform GC concretion may represent a larger venting outlet of the paleoseep with the MBB and SPN concretions situated at the outer area or borders of the paleoseep. The vertical distribution of ACCs corresponds to their horizontal distribution, because distance from the feeder fault controlled flux and flow pattern of the geofluid discharge (e.g., Fig. 5a).

\subsection{Dolomite Contents of ACCs}

Dolomitic micrite of the ACCs may have a primary (authigenic and organogenic) or a secondary (diagenetic) origin. Culture experiments (Warthmann et al. 2000; van Lith et al. 2003) and field observations (e.g., Mazzullo 2000; Meister et al. 2007) have shown that primary dolomite can precipitate in the microbially active zone where alkalinity is high and sulfate reducing bacteria are abundant. Therefore the SMTZ of a methane seep is likely a suitable milieu for dolomite precipitation.

However, seep-related carbonates with high dolomite contents usually form in deeper part or out of the sulfate reduction zone due to the requirement of high $\mathrm{Mg} / \mathrm{Ca}$ ratios (Stakes et al. 1999; Greinert et al. 2001). Modern or offshore ${ }^{13} \mathrm{C}$-depleted seep carbonates are usually predominately composed of high magnesium calcite (Stakes et al. 1999; Greinert et al. 2001; Peckmann et al. 2001; Han et al. 2008), having lower $\delta^{13} \mathrm{C}$ values than dolomite-dominated carbonates (Stakes et al. 1999).

On the other hand, dolomitization is prone to take place due to elevated temperatures during burial and diagenesis, with magnesium ions replacing calcium ions within calcium carbonates (Machel and Mountjoy 1986). Most modern and offshore methane-derived ACCs are composed of aragonite and calcite (with low to high magnesium mol\%) (Stakes et al. 1999; Greinert et al. 2001; Peckmann et al. 2001; Campbell 2006; Han et al. 2008; Crémière et al. 2012; Ge and Jiang 2012). Sediments with higher water content (i.e., closer to the sea floor) are more favorable to precipitation of aragonite than of calcite (Peckmann et al. 2001). However, aragonite is a metastable mineral and easily alternates to calcite through diagenesis. Therefore, together with dolomitization, ancient seep carbonates tend to be mostly composed of high magnesium calcite and dolomite without any aragonite.

Complicated patterns in the dolomite content of the ancient ACCs of the Chiahsien Paleoseep (Figs. 4b, c; Table 1) may be derived from the combination of primary and secondary dolomites, and probably dominated by the later (at least for ${ }^{13} \mathrm{C}$-depleted ACCs) if the mechanisms of ACC formation and mineral compositions resemble the modern offshore ACCs (cf. Stakes et al. 1999; Greinert et al. 2001; Peckmann et al. 2001; Han et al. 2008; Ge and Jiang 2012). Additionally, the dolomite contents of the ACCs of the Chiahsien Paleoseep represent different degrees and correlations between the carbon and oxygen isotopic compositions (Figs. 4b, c). The highly positive correlations between $\delta^{18} \mathrm{O}$ values and dolomite percentages of MBB type ACCs (Fig. 4c) are consistent with kinetic isotope fractionations among calcite, aragonite, high magnesium calcite, and dolomite (sensu Campbell 2006). However, dolomite percentages of GCs are not correlated with their $\delta^{18} \mathrm{O}$ values. In this situation, SPNs in Exposure A showed moderate positive correlation with their $\delta^{18} \mathrm{O}$ values; conversely, SPNs of Exposure B had highly negative correlations with their $\delta^{18} \mathrm{O}$ values (Fig. 4c). This demonstrates that isotope compositions of three types of the ACCs may not be controlled only by the original mineral compositions but also by diagenetic processes (e.g., dolomitization, dissolution and recrystallization) and mixing with calcite veins which precipitated in meteoric water. Figure $4 b$ shows negative correlations between dolomite contents and $\delta^{13} \mathrm{C}$ values of MBBs and GCs that seems to contradict the result of Stakes et al. (1999). However, it can be interpreted as the influence of mixture of relatively ${ }^{13} \mathrm{C}$-enriched calcite veins.

\subsection{Comparison with Younger Cold Seep Carbonates in Southwestern Taiwan}

The onshore Pleistocene Takanshan cold seep carbonates (Wang et al. 2006) and the offshore Pleistocene-Present ACCs from the Kaoping Slope (Huang et al. 2006) are also plotted in Fig. 4a. Overall, the carbon and oxygen isotopic compositions of most samples (besides SPNs from Exposure B) showed similar trends of lower $\delta^{13} \mathrm{C}$ values and higher $\delta^{18} \mathrm{O}$ values.

Most $\delta^{13} \mathrm{C}$ values of the Takanshan cold seep carbonates $\left(-53.7\right.$ to $-10.4 \%$ ) are within the range of the $\delta^{13} \mathrm{C}$ values for the Chiahsien ACCs from the Exposure A (-49.6 to $-17.7 \%$ ). Most $\delta^{18} \mathrm{O}$ values of the Takanshan cold seep carbonates $\left(+1.9\right.$ to $+5.0 \%$; except one sample with $\delta^{18} \mathrm{O}-5.4 \%$ ) are higher than the GC type ACCs $(-7.6$ to $+3.3 \%$ ) and are more similar to the MBB type ACCs $(+1.6$ to $+4.2 \%$ o of 
the Chiahsien Paleoseep (Fig. 4a). The $\delta^{13} \mathrm{C}$ values of these ACCs from the Kaoping Slope were lower (range, -57.6 to $-35.7 \%$ ) than the $\delta^{13} \mathrm{C}$ values for the Chiahsien ACCs (range, -49.6 to $+5.9 \%$ ) (Fig. $4 \mathrm{a}$ ). The $\delta^{18} \mathrm{O}$ values of the ACCs from the Kaoping Slope have higher values (range, +2.4 to $+7.4 \%$ o) than the Chiahsien ACCs (range -7.6 to $+4.2 \%$ ) (Fig. 4a). In addition, ACCs from the Shenhu area at the northern slope of the South China Sea (to the west and near the Kaoping Slope) also have similar carbon and oxygen isotopic compositions $\left(\delta^{13} \mathrm{C}:-57.5\right.$ to $-35.7 \%$; $\delta^{18} \mathrm{O}$ : +1.7 to $+5.3 \%$; "the Jiulong methane reef", Han et al. 2008; Ge and Jiang 2012). A summary of the spatial relationship, ages, and carbon/oxygen isotopic compositions of the asynchronous cold seep carbonates (Huang et al. 2006; Wang et al. 2006; this study) is given in Fig. 6.

Wang et al. (2006) recognized that the dolomitic mudstones of the Takanshan were cold-seep-derived carbonates which served as hardground for the growth of coral reefs. The occurrences of the Takanshan cold seep carbonates are massive, pipe-shaped, or funnel-shaped, that are similar to the triformed ACCs in this study.

The original occurrences of authigenic carbonates of the Kaoping Slope offshore southwestern Taiwan (Huang et al. 2006) are unclear due to impossibility of in situ visual observations; most of these carbonates are within the sediments and can only be sampled using gravity or piston corers. However, the deep-towed camera observations (Chen et al. 2010) in the adjacent area showed that the authigenic carbonates may be massive shaped. Their grayish white color and brecciated occurrences are also similar to the MBB type ACCs of this research. The ACCs of the Jiulong methane reef have massive, tabular, and chimney-like forms (Han et al. 2008).

In addition to the similarity of the occurrences of these onshore (ancient) and offshore (modern) ACCs, their iso- topic compositions are similar with minor discrepancies (Fig. 4a). Interestingly, the similarity of their stable carbon isotopic compositions seems to be correlated to the similarity of their occurrences. The offshore Kaoping Slope ACCs (Huang et al. 2006) yield lowest $\delta^{13} \mathrm{C}$ but also with some overlapping to the Takanshan cold seep carbonates (Wang et al. 2006) and MBB type ACCs (this research). The funnel- and pipe-shaped Takanshan cold seep carbonates have similar ranges of $\delta^{13} \mathrm{C}$ values to the GC type ACCs of the Chiahsien Paleoseep.

The oxygen isotopic compositions show some trends with the ages of the ACCs (Figs. 4a, 6): the youngest ACCs (i.e., the Kaoping Slope ACCs; Huang et al. 2006) have the highest $\delta^{18} \mathrm{O}$ values, whereas the oldest ACCs (this study) have the lowest $\delta^{18} \mathrm{O}$ values. The ACCs with ages between the youngest and oldest groups (i.e., the Takanshan cold seep carbonates; Wang et al. 2006) have intermediate $\delta^{18} \mathrm{O}$ values. If diagenetic dolomitization processes control the mineral and isotopic compositions of ACCs, our results seem inconsistent because the oxygen isotopic compositions of ACCs in the same paleoseep have complex patterns with their dolomite contents (Fig. 4c). However, the Chiahsien Paleoseep carbonates have a longer burial and exposure history; these ACCs should have a more complicated influence of diagenetic processes and/or weathering processes, therefore have a wider (and on average lower) range of $\delta^{18} \mathrm{O}$ values.

\section{CONCLUSIONS}

Several ACCs within the Early Pliocene Yenshuikeng Shale of the foreland basin sequences, southwestern Taiwan, have been preserved as a paleoseep system. Their carbon isotope compositions indicate that they are derived from the diffusion and emission of methane (Exposure A),

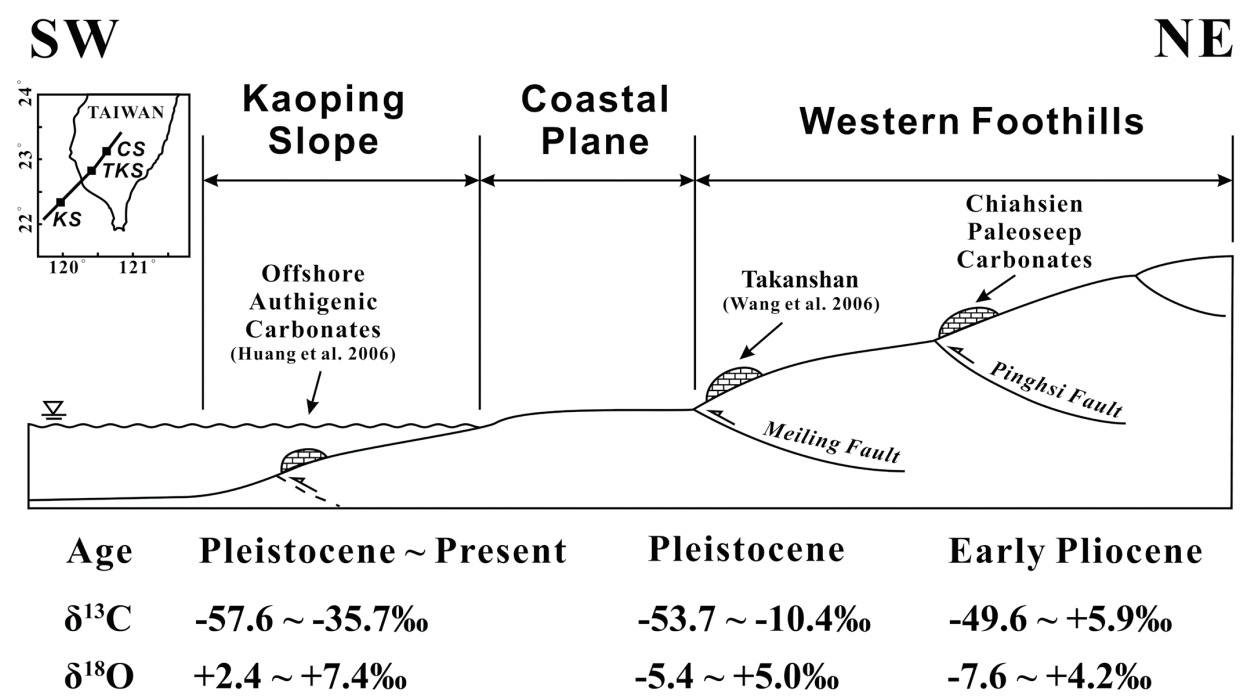

Fig. 6. Summary of the spatial relationships, ages, and ranges of carbon and oxygen isotopic compositions of three cold seep derived authigenic carbonate bodies offshore and onshore southwestern Taiwan. CS: Chiahsien Paleoseep; TKS: Takanshan Limestone; KS: Kaoping Slope. 
or from deeper sourced DIC (Exposure B). The intensity of seepage activity and flow pattern of geofluids, due to different distances from the feeder fault, controlled SMTZ depths and resulted in differences in the vertical distribution, morphologies, and sizes of ACCs. These ACCs, as well as other younger cold seep carbonates formed within the same foredeep and incorporated into the southwestern part of the Taiwan orogenic belt, represent similar occurrences and carbon isotopic compositions. However, they have undergone a longer period of diagenesis and weathering, thus the older cold seep carbonates have more complicated and ${ }^{18} \mathrm{O}$-depleted isotopic signatures than the younger carbonates. The existence of these asynchronous cold seepderived ACCs provides a well preserved geological record of hydrocarbon geofluid migrations and tectonic activities in southwestern Taiwan.

Acknowledgements This study was supported by a grant (NSC94-2116-m006-005) from the National Science Council, Taiwan. We are indebted to Prof. Wei-Teh Jiang and Mr. Po-Shu Lee for XRD analysis, and to Dr. Koichiro Masuda for identification of mollusk fossils. We also thank Prof. Ryo Matsumoto and Dr. Duo-Fu Chen for discussions, and thank three anonymous reviewers whose valuable comments greatly help to improve this paper.

\section{REFERENCES}

Aharon, P., 2000: Microbial processes and products fueled by hydrocarbons at submarine seeps. In: Riding, R. E. and S. M. Awramik (Eds.), Microbial Sediments, Springer-Verlag Berlin Heidelberg, 270-281.

Aiello, I. W., 2005: Fossil seep structures of the Monterey Bay region and tectonic/structural controls on fluid flow in an active transform margin. Palaeogeogr. Palaeoclimatol. Palaeoecol., 227, 124-142, doi: 10.1016/j. palaeo.2005.04.027. [Link]

Barnes, P. M., G. Lamarche, J. Bialas, S. Henrys, I. Pecher, G. L. Netzeband, J. Greinert, J. J. Mountjoy, K. Pedley, and G. Crutchley, 2010: Tectonic and geological framework for gas hydrates and cold seeps on the Hikurangi subduction margin, New Zealand. Mar. Geol., 272, 2648, doi: 10.1016/j.margeo.2009.03.012. [Link]

Borowski, W. S., C. K. Paull, and W. Ussler III, 1996: Marine pore-water sulfate profiles indicate in situ methane flux from underlying gas hydrate. Geology, 24, 655658, doi: 10.1130/0091-7613(1996)024<0655:MPWS$\mathrm{PI}>2.3 . \mathrm{CO} ; 2$. [Link]

Bouchet, P. and R. von Cosel, 2004: The world's largest lucinid is an undescribed species from Taiwan (Mollusca: Bivalvia). Zool. Stud., 43, 704-711.

Campbell, K. A., 2006: Hydrocarbon seep and hydrothermal vent paleoenvironments and paleontology: Past developments and future research directions. Palaeo- geogr. Palaeoclimatol. Palaeoecol., 232, 362-407, doi: 10.1016/j.palaeo.2005.06.018. [Link]

Chen, S. C., S. K. Hsu, C. H. Tsai, C. Y. Ku, Y. C. Yeh, and Y. Wang, 2010: Gas seepage, pockmarks and mud volcanoes in the near shore of SW Taiwan. Mar. Geophys. Res., 31, 133-147, doi: 10.1007/s11001-010-9097-6. [Link]

Chien, C. W., C. Y. Huang, Z. Chen, H. C. Lee, and R. Harris, 2012: Miocene shallow-marine cold seep carbonate in fold-and-thrust Western Foothills, SW Taiwan. J. Asian Earth Sci., 56, 200-211, doi: 10.1016/j. jseaes.2012.05.013. [Link]

Chiu, J. K., W. H. Tseng, and C. S. Liu, 2006: Distribution of gassy sediments and Mud volcanoes offshore southwestern Taiwan. Terr. Atmos. Ocean. Sci., 17, 703-722.

Chung, C. T., 1962: Geology of the Hunghuatzu anticline, Kaohsiung, Taiwan. Petrol. Geol. Taiwan, 1, 31-50.

Conti, S., D. Fontana, S. Mecozzi, G. Panieri, and G. A. Pini, 2010: Late Miocene seep-carbonates and fluid migration on top of the Montepetra intrabasinal high (Northern Apennines, Italy): Relations with synsedimentary folding. Sediment. Geol., 231, 41-54, doi: 10.1016/j. sedgeo.2010.08.001. [Link]

Crémière, A., C. Pierre, M. M. Blanc-Valleron, T. Zitter, M. N. Çă̆atay, and P. Henry, 2012: Methane-derived authigenic carbonates along the North Anatolian fault system in the Sea of Marmara (Turkey). Deep-Sea Res. Part I-Oceanogr. Res. Pap., 66, 114-130, doi: 10.1016/j.dsr.2012.03.014. [Link]

Gay, A., M. Lopez, C. Berndt, and M. Séranne, 2007: Geological controls on focused fluid flow associated with seafloor seeps in the Lower Congo Basin. Mar. Geol., 244, 68-92, doi: 10.1016/j.margeo.2007.06.003. [Link]

Ge, L. and S. Y. Jiang, 2012: Sr isotopic compositions of cold seep carbonates from the South China Sea and the Panoche Hills (California, USA) and their significance in palaeooceanography. J. Asian Earth Sci., 65, 34-41, doi: 10.1016/j.jseaes.2012.10.016. [Link]

Greinert, J., G. Bohrmann, and E. Suess, 2001: Gas hydrateassociated carbonates and methane-venting at Hydrate Ridge: Classification, distribution, and origin of authigenic lithologies. In: Paull C. K. and W. P. Dillon (Eds.), Natural Gas Hydrates: Occurrence, Distribution, and Detection, Geophys. Monogr. Ser., Vol. 124, AGU, Washington, D. C., 99-113, doi: 10.1029/ GM124p0099. [Link]

Han, X., E. Suess, Y. Huang, N. Wu, G. Bohrmann, X. Su, A. Eisenhauer, G. Rehder, and Y. Fang, 2008: Jiulong methane reef: Microbial mediation of seep carbonates in the South China Sea. Mar. Geol., 249, 243-256, doi: 10.1016/j.margeo.2007.11.012. [Link]

Huang, C. Y., W. Y.Wu, C.P.Chang, S. Tsao, P. B. Yuan, C. W. Lin, and X. Kuan-Yuan, 1997: Tectonic evolution 
of accretionary prism in the arc-continent collision terrane of Taiwan. Tectonophysics, 281, 31-51, doi: 10.1016/S0040-1951(97)00157-1. [Link]

Huang, C. Y., P. B. Yuan, C. W. Lin, T. K. Wang, and C. P. Chang, 2000: Geodynamic processes of Taiwan arc-continent collision and comparison with analogs in Timor, Papua New Guinea, Urals and Corsica. Tectonophysics, 325, 1-21, doi: 10.1016/S00401951(00)00128-1. [Link]

Huang, C. Y., K. Xia, P. B. Yuan, and P. G. Chen, 2001: Structural evolution from Paleogene extension to Latest Miocene-Recent arc-continent collision offshore Taiwan: Comparison with on land geology. J. Asian Earth Sci., 19, 619-639, doi: 10.1016/S1367-9120(00)000651. [Link]

Huang, C. Y., C. W. Chien, M. Zhao, H. C. Li, and Y. Iizuka, 2006: Geological study of active cold seeps in the syn-collision accretionary prism Kaoping Slope off SW Taiwan. Terr. Atmos. Ocean. Sci., 17, 679-702.

Judd, A. and M. Hovland, 2007: Seabed Fluid Flow: The Impact on Geology, Biology and the Marine Environment, Cambridge University Press, $475 \mathrm{pp}$, doi: 10.1017/CBO9780511535918. [Link]

Lein, A. Yu., 2004: Authigenic carbonate formation in the ocean. Lithol. Miner. Resour., 39, 1-30, doi: 10.1023/B :LIMI.0000010767.52720.8f. [Link]

Levin, L. A., 2005: Ecology of cold seep sediments: Interactions of fauna with flow, chemistry and microbes. Oceanogr. Mar. Biol. Annu. Rev., 43, 1-46.

Liu, C. S., S. Y. Liu, S. E. Lallemand, N. Lundberg, and D. L. Reed, 1998: Digital Elevation Model Offshore Taiwan and Its Tectonic Implications. Terr. Atmos. Ocean. Sci., 9, 705-738.

Liu, C. S., S. Morita, Y. H. Liao, C. Y. Ku, H. Machiyama, S. Lin and W. Shoh, 2008: High-resolution seismic images of the Formosa Ridge off Southwestern Taiwan where "hydrothermal" chemosynthetic community is present at a cold sepp site. Proceedings of the 6th International Conference on Gas Hydrates, Vancouver, British Columbia, Canada.

Machel, H. G. and E. W. Mountjoy, 1986: Chemistry and environments of dolomitization - a reappraisal. Earth-Sci. Rev., 23, 175-222, doi: 10.1016/0012-8252(86)900176. [Link]

Mazzullo, S. J., 2000: Organogenic dolomitization in peritidal to deep-sea sediments. J. Sediment. Res., 70, 10-23, doi:10.1306/2dc408f9-0e47-11d7-8643000102c1865d. [Link]

Meister, P., J. A. Mckenzie, C. Vasconcelos, S. Bernasconi, M. Frank, M. Gutjahr, and D. P. Schrag, 2007: Dolomite formation in the dynamic deep biosphere: Results from the Peru Margin. Sedimentology, 54, 1007-1031, doi: 10.1111/j.1365-3091.2007.00870.x. [Link]

Mumme, W. G., G. Tsambourakis, I. C. Madsen, and R.
J. Hill, 1996: Improved petrological modal analyses from X-ray powder diffraction data by use of the Rietveld method; Part II, selected sedimentary rocks. $J$. Sediment. Res., 66, 132-138, doi: 10.1306/D42682D42B26-11D7-8648000102C1865D. [Link]

Netzeband, G. L., A. Krabbenhoeft, M. Zillmer, C. J. Petersen, C. Papenberg, and J. Bialas, 2010: The structures beneath submarine methane seeps: Seismic evidence from Opouawe Bank, Hikurangi Margin, New Zealand. Mar. Geol., 272, 59-70, doi: 10.1016/j.margeo.2009.07.005. [Link]

Peckmann, J. and V. Thiel, 2004: Carbon cycling at ancient methane-seeps. Chem. Geol., 205, 443-467, doi: 10.1016/j.chemgeo.2003.12.025. [Link]

Peckmann, J., A. Reimer, U. Luth, C. Luth, B. T. Hansen, C. Heinicke, J. Hoefs, and J. Reitner, 2001: Methanederived carbonates and authigenic pyrite from the northwestern Black Sea. Mar. Geol., 177, 129-150, doi: 10.1016/S0025-3227(01)00128-1. [Link]

Rietveld, H. M., 1967: Line profiles of neutron powder-diffraction peaks for structure refinement. Acta Crystallogr., 22, 151-152, doi: 10.1107/S0365110X67000234. [Link]

Roberts, H. H., 2001: Fluid and gas expulsion on the northern Gulf of Mexico continental slope: Mud-prone to mineral-prone responses. In: Paull, C. K. and W. P. Dillon (Eds.), Natural Gas Hydrates: Occurrence, Distribution, and Detection, Geophys. Monogr. Ser., Vol. 124, AGU, Washington, D. C., 145-161, doi: 10.1029/ GM124p0145. [Link]

Sample, J. C. and M. R. Reid, 1998: Contrasting hydrogeologic regimes along strike-slip and thrust faults in the Oregon convergent margin: Evidence from the chemistry of syntectonic carbonate cements and veins. Geol. Soc. Am. Bull., 110, 48-59, doi: 10.1130/0016-7606(19 98) $110<0048$ :CHRASS >2.3.CO;2. [Link]

Shih, T. T., 1967: A survey of the active mud volcanoes in Taiwan and a study of their types and the character of the mud. Petrol. Geol. Taiwan, 5, 259-311.

Sibuet, M. and K. Olu, 1998: Biogeography, biodiversity and fluid dependence of deep-sea cold-seep communities at active and passive margins. Deep-Sea Res. Part II-Top. Stud. Oceanogr., 45, 517-567, doi: 10.1016/ S0967-0645(97)00074-X. [Link]

Stakes, D. S., D. Orange, J. B. Paduan, K. A. Salamy, and N. Maher, 1999: Cold-seeps and authigenic carbonate formation in Monterey Bay, California. Mar. Geol., 159, 93-109, doi: 10.1016/S0025-3227(98)00200-X. [Link]

Stanley, S. M., 1970: Relation of Shell form to Life Habits of the Bivalvia (Mollusca), Geological Society of America, 296 pp.

Sun, C. H., S. C. Chang, C. L. Kuo, J. C. Wu, P. H. Shao, and J. N. Oung, 2010: Origins of Taiwan's mud volcanoes: Evidence from geochemistry. J. Asian Earth 
Sci., 37, 105-116, doi: 10.1016/j.jseaes.2009.02.007. [Link]

Sung, Q., C. W. Lin, W. H. Lin, and W. C. Lin, 2000: Explanatory text of the geologic map of Taiwan scale 1:50,000; Sheet 51. Central Geological Survey, Ministy of Economic Affairs, Chiahsien (Map).

Suppe, J., 1984: Kinematics of arc-continent collision, flipping of subduction, and back-arc spreading near Taiwan. Mem. Geol. Soc. China, 6. 21-33.

Taylor, J. D. and E. A. Glover, 2000: Functional anatomy, chemosymbiosis and evolution of the Lucinidae. In: Harper, E. M., J. D. Taylor, and J. A. Crame (Eds.), The Evolutionary Biology of the Bivalvia, Geoogical Society of London, Special Publication, Vol. 177, 207225, doi: 10.1144/GSL.SP.2000.177.01.12. [Link]

Taylor, J. D. and E. A. Glover, 2009: A giant lucinid bivalve from the Eocene of Jamaica - Systematics, life habits and chemosymbiosis (Mollusca: Bivalvia: Lucinidae). Palaeontology, 52, 95-109, doi: 10.1111/j.14754983.2008.00839.x. [Link]

Ting, H. H., C. Y. Huang, and L. C. Wu, 1991: Paleoenvironments of the Late Neogene sequences along the Nantzuhsien River, southern Taiwan. Petrol. Geol. Taiwan, 26, 121-149.

Toby, B. H., 2006: $R$ factors in Rietveld analysis: How good is good enough? Powder Diffr., 21, 67-70, doi: 10.1154/1.2179804. [Link]

Tsunogai, U., N. Yoshida, and T. Gamo, 2002: Carbon isotopic evidence of methane oxidation through sulfate reduction in sediment beneath cold seep vents on the seafloor at Nankai Trough. Mar. Geol., 187, 145-160, doi: 10.1016/S0025-3227(02)00263-3. [Link]

van Lith, Y., R. Warthmann, C. Vasconcelos, and J. A.
Mckenzie, 2003: Sulphate-reducing bacteria induce low-temperature Ca-dolomite and high $\mathrm{Mg}$-calcite formation. Geobiology, 1, 71-79, doi: 10.1046/j.14724669.2003.00003.x. [Link]

Wang, S. W., S. Y. Gong, H. S. Mii, and C. F. Dai, 2006: Cold-seep Carbonate Hardgrounds as the Initial Substrata of Coral Reef Development in a Siliciclastic Paleoenvironment of Southwestern Taiwan. Terr. Atmos. Ocean. Sci., 17, 405-427.

Warthmann, R., Y. van Lith, C. Vasconcelos, J. A. McKenzie, and A. M. Karpoff, 2000: Bacterially induced dolomite precipitation in anoxic culture experiments. Geology, 28, 1091-1094, doi: 10.1130/0091-7613(200 0)28<1091:BIDPIA > 2.0.CO;2. [Link]

Yang, T. F., G. H. Yeh, C. C. Fu, C. C. Wang, T. F. Lan, H. F. Lee, C. H. Chen, V. Walia, and Q. C. Sung, 2004: Composition and exhalation flux of gases from mud volcanoes in Taiwan. Environ. Geol., 46, 1003-1011, doi: 10.1007/s00254-004-1086-0. [Link]

Yeh, M. G. and Y. L. Chang, 1991: The ichnofacies study of the Ailiaochiao Formation - the Changchihkeng Formation Chiahsien-Meinung Area, Kaohsiung. Petrol. Geol. Taiwan, 26, 151-181.

Young, R. A., 1993: Introduction to the Rietveld method. In: Young, R. A. (Ed.), The Rietveld Method, Oxford University Press, 1-38.

Zitter, T. A. C., P. Henry, G. Aloisi, G. Delaygue, M. N. Çağatay, B. Mercier de Lepinay, M. Al-Samir, F. Fornacciari, M. Tesmer, A. Pekdeger, K. Wallmann, and G. Lericolais, 2008: Cold seeps along the main Marmara Fault in the Sea of Marmara (Turkey). Deep-Sea Res. Part I-Oceanogr. Res. Pap., 55, 552-570, doi: 10.1016/j.dsr.2008.01.002. [Link] 